\title{
Quality of life assessment after pancreatic enzyme replacement therapy in chronic pancreatitis
}

\author{
László Czakó PhD¹, Tamás Takács PhD¹, Peter Hegyi PhD¹ ,László Prónai PhD², Zsolt Tulassay DSc², Lilla Lakner³ \\ Zoltán Döbrönte $\mathrm{PhD}^{3}$, Krisztina Boda $\mathrm{PhD}^{4}$, János Lonovics $\mathrm{DSc}^{1}$
}

\begin{abstract}
L Czakó, T Takács, P Hegyi, et al. Quality of life assessment after pancreatic enzyme replacement therapy in chronic pancreatitis. Can J Gastroenterol 2003;17(10):597-603.
\end{abstract}

GOALS: To evaluate the quality of life (QoL) of patients with chronic pancreatitis before and after pancreatic enzyme replacement therapy in a prospective, multicentre, follow-up study.

STUDY: Two groups of patients were evaluated. Group 1 consisted of 31 patients with newly diagnosed chronic pancreatitis who had never been treated with pancreatic enzyme preparations. Group 2 consisted of 39 patients whose disease was diagnosed on average 3.4 years before the start of the study. The latter group of patients had undergone pancreatic enzyme replacement therapy, but during follow-up this treatment proved to be insufficient. The dose of pancreatic enzyme replacement therapy was tailored in accordance with the degree of pancreatic exocrine insufficiency measured by means of exocrine pancreatic function tests. A modified European Organizaton for Research and Treatment of Cancer Quality of Life Questionnaire Core 30 (EORTC QLQ-C30) was used to assess QoL. RESULTS: The social functioning and financial strain were significantly better, while the levels of hope and confidence were significantly reduced in group 1 compared with group 2 . A significant gain in body weight and a significantly reduced defecation rate were found in both groups one month after the beginning of the pancreatic enzyme replacement therapy when compared with the pretreatment values. The prevalence of general and disease-specific symptoms and the intensity of pain were reduced in both groups after one month of enzyme substitution therapy. The working ability, the financial strain and the overall QoL scores were improved significantly in both groups, while the cognitive functioning score was found to be significantly improved during the follow-up only in group 1 . The overall increase in the QoL score correlated significantly with the increase in body weight and the decrease in defecation number in both groups. CONCLUSIONS: Pancreatic enzyme replacement therapy in patients with chronic pancreatitis not only reduced the extent of steatorrhea and pain, but also significantly improved a variety of other symptoms and the patient's QoL. Individually tailored enzyme replacement therapy improved the QoL not only in the untreated chronic pancreatitis patients, but also in the inadequately treated group. This study demonstrated that the EORTC QLQ-C30 questionnaire, with the addition of two further questions about steatorrhea, is a useful tool for the evaluation of $\mathrm{QoL}$ in patients with chronic pancreatitis.

Key Words: Chronic pancreatitis; EORTC QLQ-C30; Medical treatment; Pain; Pancreatic enzyme substitution; Pancreatic exocrine insufficiency; Quality of life

\author{
Évaluation de la qualité de vie après une thérapie de remplace- \\ ment de l'enzyme pancréatique dans des cas de pancréatite \\ chronique.
}

OBJECTIFS : Évaluer la qualité de vie (QDV) des patients souffrant de pancréatite chronique avant et après une thérapie de remplacement de l'enzyme pancréatique au cours d'une étude multicentrique, prospective et de suivi.

ÉTUDE : On a évalué deux groupes de patients. Le groupe 1 comprenait 31 patients souffrant d'une pancréatite chronique nouvellement diagnostiquée qui n'avaient jamais été traités avec des préparations d'enzymes pancréatiques. Le groupe 2, quant à lui, était composé de 39 patients chez qui on avait diagnostiqué la maladie en moyenne 3,4 années avant le début de cette étude. Le premier groupe de patients avait entrepris un traitement de remplacement de l'enzyme pancréatique mais durant le suivi, ce traitement s'est révélé insuffisant. On a personnalisé la dose du traitement de remplacement de l'enzyme pancréatique conformément au degré d'insuffisance exocrine évaluée au moyen de tests de la fonction pancréatique exocrine. Les analyses de qualité de vie ont été réalisées avec le questionnaire de qualité de vie QLQ-30 de l'Organisation européenne de recherche sur le traitement du cancer 30 (OERTC QLQC30).

RÉSULATS: Le fonctionnement social et les contraintes financières des patients se sont considérablement améliorés, alors que les niveaux d'espoir et de confiance ont considérablement diminué dans le groupe 1 comparativement au groupe 2 . On a observé un gain pondéral important et un taux de défécation réduit dans les deux groupes un mois après le début du traitement de remplacement de l'enzyme pancréatique comparativement aux valeurs notées avant le traitement. La prévalence de symptômes généraux et particuliers à la maladie et l'intensité de la douleur ont diminué dans les deux groupes après un mois de thérapie de substitution enzymatique. La capacité de travail, les contraintes financières et les pointages de qualité de vie globaux se sont améliorés considérablement dans les deux groupes, tandis que le pointage de fonctionnement cognitif s'est considérablement amélioré lors du suivi, mais seulement chez le groupe 1. L'augmentation globale du pointage de la qualité de vie était corrélée de façon significative avec l'augmentation de poids et la diminution du nombre de défécations dans les deux groupes. CONCLUSIONS: La thérapie du traitement de remplacement de l'enzyme pancréatique chez les patients souffrant de pancréatite chronique a non seulement réduit l'ampleur de la stéatorrhée et l'intensité de la douleur, mais a également amélioré une variété d'autres symptômes et la qualité de vie du patient. La thérapie de traitement de remplacement de l'enzyme pancréatique personalisée individuellement a amélioré non seulement la qualité de vie des patients souffrant de pancréatite chronique non traités, mais également chez un groupe qui n'était pas traité adéquatement. Cette étude a démontré que le questionnaire OERTC QLQ-C30 avec l'ajout de questions supplémentaires sur la stéatorrhée constitue un outil utile pour évaluer la qualité de vie chez les patients souffrant de pancréatite chronique.

\footnotetext{
${ }^{1}$ First Department of Medicine, ${ }^{2}$ Second Department of Medicine, Semmelweis University, Budapest; ${ }^{3}$ Second Department of Medicine, Markusovszy Teaching Hospital, Szombathely, Hungary; ${ }^{4}$ Department of Medical Informatics, University of Szeged, Szeged

Correspondence and reprints: Dr László Czakó, First Department of Medicine, University of Szeged, Szeged, PO Box:469, H-6701, Hungary.

Telephone 36-62-545201, fax 36-62-545185, e-mail czal@in1 st.szote.u-szeged.hu

Received for publication March 26, 2003. Accepted July 31, 2003
} 
$\mathrm{T}$ he pathophysiology of chronic pancreatitis is puzzling, the classification of the disease is unsatisfactory and no standardized treatment is available (1-4). The application of new treatment modalities without controlled interdisciplinary studies intensifies the problem. Earlier studies on the natural course of chronic pancreatitis and the effects of different treatment modalities have focused on the morbidity and mortality of the disease, the onset of an exocrine and an endocrine insufficiency, and the severity of pain (1). Pain is the leading symptom of chronic pancreatitis, but it reflects only one aspect of the multidimensionality of the quality of life ( $\mathrm{QoL})$. In a benign disease such as chronic pancreatitis, the ultimate aim of any treatment modality must be an improvement of the patient's QoL. Assessment of the QoL is currently receiving increasing attention as a standard evaluation criterion for treatment options targeting patients with chronic pancreatitis.

QoL assessment was first applied for evaluation of the outcome in cancer treatment (5-7). The European Organization for the Research and Treatment of Cancer (EORTC) demonstrated that the Quality of Life Questionnaire Core 30 (QLQC30) QoL measurement system is a practical, reliable, valid and cross-culturally applicable method (7). The QLQ-C30 incorporates nine multi-item scales: five functional scales (physical, role, cognitive, emotional and social); three symptom scales (fatigue, pain, and nausea and vomiting); and an overall health and QoL scale relevant to a broad range of cancer patients irrespective of the specific diagnosis. This core questionnaire has been supplemented by a diagnosis-specific symptom scale, such as that for pancreatic cancer, a treatment scale and an overall hope and confidence scale (7).

Patients with chronic pancreatitis present the same symptoms (pain, loss of appetite, weight loss, emesis and jaundice) as seen in pancreatic cancer. Although the QLQ-C30 questionnaire was originally developed for clinical oncological trials, it also appears to be a promising tool for evaluation of the QoL of patients with chronic pancreatitis. Recent studies have demonstrated that the application of this questionnaire in chronic pancreatitis is promising: it fulfils the criteria of reliability, validity and responsiveness (8-13). Few investigations have been made of the QoL of patients with chronic pancreatitis after different treatment modalities (8-13). One study recently evaluated the QoL in chronic pancreatitis patients after the medical management of pain, and endocrine and exocrine insufficiencies (9). Whereas the alleviation of steatorrhea and pain during pancreatic enzyme replacement therapy in chronic pancreatitis has been demonstrated (14-17), the effect of this treatment on QoL is not known. By employing the modified QLQ-C30 questionnaire in this prospective, multicentre, follow-up study, we have evaluated the $\mathrm{QoL}$ in patients with chronic pancreatitis who underwent pancreatic enzyme replacement therapy.

\section{PATIENTS AND METHODS}

\section{Inclusion criterion}

A prospective, multicentre, follow-up study was performed. The inclusion criterion, a diagnosis of chronic pancreatitis, was based on morphological and functional tests. Establishment of the morphological diagnosis of chronic pancreatitis included the use of abdominal ultrasonography, computed tomography, magnetic resonance cholangiopancreatography and endoscopic retrograde cholangiopancreatography. The patients were divided into a mild or a severe exocrine insufficiency group, depending on the results
TABLE 1

Characteristics of the study patients

\begin{tabular}{lll}
\hline & Group 1 & Group 2 \\
\hline Number of patients & 31 & 39 \\
Age & $53.0(31-79)$ & $53.2(35-72)$ \\
Sex (male/female) & $29 / 2$ & $37 / 2$ \\
Chronic alcoholism & 22 & 28 \\
Diabetes mellitus (yes/no) & $6 / 25$ & $9 / 30$ \\
Pancreatic operation (yes/no) & $3 / 28$ & $11 / 28$ \\
Clinical symptoms (yes/no) & & \\
$\quad$ Pain & $30 / 1$ & $37 / 2$ \\
$\quad$ Steatorrhea & $12 / 19$ & $23 / 16$ \\
$\quad$ Bloating & $28 / 3$ & $34 / 5$ \\
$\quad$ Defecation/week & $12.1 \pm 1.1$ & $13.9 \pm 1.8$ \\
Degree of exocrine & $20 / 11$ & $14 / 25$ \\
pancreatic insufficiency (mild/severe) & \\
\hline
\end{tabular}

of the pancreatic function tests and the degree of steatorrhea. The exocrine pancreatic function was assessed by performing the Lundh test (mild - fewer than six abnormal parameters; severe more than six abnormal parameters) (18), the lipiodol test (normal - greater than $2.8 \mathrm{mEq} / 24 \mathrm{~h}$ ) (19), estimation of the fecal elastase (normal - greater than $200 \mu \mathrm{g} / \mathrm{g}$; mild - less than $200 \mu \mathrm{g} / \mathrm{g}$; severe - less than $100 \mu \mathrm{g} / \mathrm{g}$ feces) (20) and chymotrypsin (normal - greater than $20 \mathrm{U} / g$; mild - less than $20 \mathrm{U} / g$; severe less than $6 \mathrm{U} / \mathrm{g}$ feces) (21) concentrations.

\section{Patients}

The characteristics of the study sample are shown in Table 1. Eighty-nine consecutive patients were invited to participate in this study, and 75 of them consented, which corresponds to $86 \%$ of those invited. Five of the 75 enrolled patients were lost to followup; 70 patients completed the trial. Twenty-six, 24 and 20 patients were recruited by the participating institutions, respectively, which were tertiary academic centres.

Two groups of patients were evaluated. Group 1 consisted of patients with newly diagnosed chronic pancreatitis who had never been treated with pancreatic enzyme preparations (31 patients, 29 men and two women, mean age 53.0 years, range 31 to 79 years). Group 2 consisted of patients whose disease was diagnosed on average 3.4 years (range one to 14 years) before the start of this study ( 39 patients, 37 men and two women, mean age 53.2 years, range 35 to 72 years). Group 2 underwent pancreatic enzyme replacement therapy, but during the follow-up this treatment proved to be insufficient. All group 2 patients presented with abdominal pain, weight loss and steatorrhea (Table 1).

The etiology of the chronic pancreatitis involved alcohol overindulgence in 22 patients in group 1, and 28 patients in group 2. Three and 11 patients, respectively, had previously undergone pancreatic surgery (the Whipple or the Beger procedure, cystogastrostomy, cystojejunostomy or Wirsungo-gastrostomy) in groups 1 and 2 , while six and nine patients suffered from diabetes mellitus in groups 1 and 2, respectively (Table 1).

\section{Study design}

The patients in both groups received dietary counselling and an enteric coated microsphere ( 1 to $2 \mathrm{~mm}$ in diameter) porcine pancreatic enzyme preparation three times a day. The enzyme replacement therapy depended on the grade of the exocrine pancreatic 
insufficiency; patients with a mild exocrine pancreatic insufficiency received a preparation with lower enzyme content $(10,000 \mathrm{Ph}$ Eur units lipase, $8000 \mathrm{Ph}$ Eur units amylase and $600 \mathrm{Ph}$ Eur units protease), while those with a severe exocrine pancreatic insufficiency received a preparation with higher enzyme content $(25,000$ $\mathrm{Ph}$ Eur units lipase, 18,000 Ph Eur units amylase and $1000 \mathrm{Ph}$ Eur units protease). Each patient in both groups received an $\mathrm{H}_{2}$ receptor blocker regularly, and analgesic when needed.

The patients' QoL was assessed before and one month after the medical treatment by means of the modified QLQ-C30 questionnaire. The questionnaire was completed by the patients themselves alone and the administrative work was done by gastroenterologists (LC, LP, LL). The questionnaire consisted of a core with 30 general applicable, unspecific items, including a functional scale (items 1 to 5), a working ability scale (items 6 and 7), a general symptom scale (items 8 to 19), scales on cognitive (items 20 and 25), emotional (items 21 to 24) and social (items 26 and 27) functioning, a financial strain scale (item 28) and an overall QoL scale (items 29 and 30) (Figure 1) (7). An attached module with 22 specific items included a disease-specific symptom scale (items 31 to 48 ), a treatment strain scale (items 49 to 51), and an overall hope and confidence scale (item 52). Because the QLQ-C30 questionnaire does not contain any question on steatorrhea, the original questionnaire was supplemented with two additional questions covering this symptom (items 47 and 48). Abdominal pain, as one of the leading symptoms of chronic pancreatitis, was also assessed (items 9, 19 and 41 to 46 ).

There are two choices in the scales for items 1 to 7 , four choices for items 8 to 28 and 31 to 48, and seven choices for items 29, 30, 49 and 52. Items 50 and 51 allow narrative answers. For ease of interpretation, all scales and item scores were lineally transformed to a 0 to 100 scale. For the five functional scales and the overall QoL scale, a higher score reflects a better level of functioning. For the symptom-oriented scales, a higher score indicates a more severe level of symptoms.

\section{Statistical analysis}

The parametric data are expressed as means \pm SD. Nonparametric data are expressed as means and range. The paired Student's $t$ test was performed to evaluate the significance of differences between the pretreatment and follow-up body weight and defecation rate. The Wilcoxon rank test was used to estimate the significance of differences between pretreatment and follow-up QoL scores, and the Mann-Whitney $U$ test test to evaluate the significance of differences between groups 1 and 2. Relationships between variables were characterized by the nonparametric Spearman rank correlation. $\mathrm{P}<0.05$ was accepted as significant.

\section{RESULTS}

The questionnaire was well accepted by the patient population (70\% of whom were regular alcohol consumers) and it was completed by the patients themselves in approximately 15 mins, without difficulty. Compliance by patients in this study was very high (only one subject failed to complete the questionnaire), probably due to careful and detailed counselling of the patients.

Patients in group 2 had significantly more severe exocrine pancreatic insufficiency as measured by functional tests, and greater steatorrhea when compared with group 1. More patients underwent surgical therapy in group 2 than in group 1 , and all the patients in group 2 failed to respond to medical therapy. Therefore, the patients in group 2 appeared to have more severe chronic pancreatitis.

The pretreatment and follow up QoL scores for each scale are displayed in Tables 2 and 3. Although the baseline score of social functioning and financial strain were significantly better, the hope and confidence were significantly reduced in group 1 compared with group 2. At one month, the social functioning and financial strain were not significantly different between the two groups. Before the start of the study, the mean body weight loss was $7.4 \pm 1.8 \mathrm{~kg}$ in group 1 and $4.7 \pm 1.3 \mathrm{~kg}$ in group 2. A significant gain in body weight was found in both groups one month after the beginning of pancreatic enzyme replacement therapy, compared with the pretreatment values. The defecation rate was significantly reduced by $22 \%$ in group 1 and by $17 \%$ in group 2 during follow-up. The prevalence of general and disease-specific symptoms was reduced in both groups after one month of enzyme substitution therapy. The pain score decreased by $24 \%$ in group 1 and by $22 \%$ in group 2 during follow-up. The working ability, the financial strain and the overall QoL score were improved significantly in both groups, while the cognitive functioning score was significantly improved at follow-up only in group 1 . The improvement in the physical status was statistically not significant in either group at the one-month follow-up. The overall QoL improved by $8.8 \%$ and $9.2 \%$ in groups 1 and 2 , respectively. The overall increase in the QoL score correlated significantly with the increase in body weight and the decrease in defecation number in both groups $(0.77$ and 0.89 in group $1[\mathrm{P}<0.001]$ and 0.87 and 0.74 in group $2[\mathrm{P}<0.001]$, respectively).

\section{DISCUSSION}

Chronic pancreatitis is a dynamic disease characterized by progressive destruction of the pancreatic parenchyma with fibrosis and calcification, and by pain and progressive impairment of the pancreatic functions (4). The 10-year mortality rate is unacceptably high (22). Despite recent advances in the conservative and operative treatment of chronic pancreatitis, the treatment of the disease remains a major challenge and causal therapy is still not available (2).

New therapeutic options (medical treatment, endoscopic interventions, extracorporal shock wave lithotripsy and organpreserving surgical procedures) that are available for the treatment of chronic pancreatitis have been evaluated with regards to their effects on pain, morbidity, mortality, and endocrine and exocrine functions (23-30). Because the ultimate goal of any treatment of chronic pancreatitis is to maximize the patient's QoL, this parameter should be assessed when new therapeutic modalities are evaluated. The EORTC study group presented a reliable and valid questionnaire for the measurement of the QoL in patients with malignant diseases (7). Recent studies have demonstrated that this questionnaire is also a valid and reliable tool for assessment of the QoL of patients with chronic pancreatitis (8-13).

In the present study, the modified EORTC questionnaire was applied before and after enzyme replacement therapy in patients with chronic pancreatitis. We evaluated the QoL in two chronic pancreatitis patient populations: one group with newly diagnosed chronic pancreatitis who had never been treated, and another group who had already been treated with pancreatic enzyme therapy, but this treatment proved to be insufficient at the follow-up. As anticipated, the main symptoms of chronic pancreatitis (pain and steatorrhea) were 
1. Do you have any trouble doing strenuous activities, like carrying a heavy shopping bag or a suitcase?

\begin{tabular}{l|l}
\hline 2. & Do you have any trouble taking a long walk?
\end{tabular}

3. Do you have any trouble taking a short walk outside the house?

\begin{tabular}{|l|l}
\hline 4. & Do you have to stay in bed or a chair for most of the day?
\end{tabular}

5. Do you need help with eating, dressing, washing yourself, or using the toilet?

6. Are you limited in any way in either doing your work or doing household jobs?

7. $\quad$ Are you completely unable to work at a job or to do household jobs?

\begin{tabular}{|c|c|c|c|c|c|}
\hline & & Not at all & A little & Quite a bit & Very much \\
\hline 8. & Were you short of breath? & & & & \\
\hline 9. & Have you had pain? & & & & \\
\hline 10. & Did you need to rest? & & & & \\
\hline 11. & Have you had trouble sleeping? & & & & \\
\hline 12. & Have you felt weak? & & & & \\
\hline 13. & Have you lacked appetite? & & & & \\
\hline 14. & Have you felt nauseated? & & & & \\
\hline 15. & Have you vomited? & & & & \\
\hline 16. & Have you been constipated? & & & & \\
\hline 17. & Have you had diarrhea? & & & & \\
\hline 18. & Were you tired? & & & & \\
\hline 19. & Did pain interfere with your daily activities? & & & & \\
\hline 20. & $\begin{array}{l}\text { Have you had difficulties in concentrating on things, like } \\
\text { reading a newspaper or watching } \\
\text { television? }\end{array}$ & & & & \\
\hline 21. & Did you feel tense? & & & & \\
\hline 22. & Did you worry? & & & & \\
\hline 23. & Did you feel irritable? & & & & \\
\hline 24. & Did you feel depressed? & & & & \\
\hline 25. & Have you had difficulty remembering things? & & & & \\
\hline 26. & $\begin{array}{l}\text { Has your physical condition or medical treatment } \\
\text { interfered with your family life? }\end{array}$ & & & & \\
\hline 27. & $\begin{array}{l}\text { Has your physical condition or medical treatment } \\
\text { interfered with your social activities? }\end{array}$ & & & & \\
\hline 28. & $\begin{array}{l}\text { Has your physical condition or medical treatment caused } \\
\text { you financial difficulties? }\end{array}$ & & & & \\
\hline
\end{tabular}

For the following questions please circle the number between 1 and 7 that best applies to you.

29. How would you rate your overall physical condition during the past week?

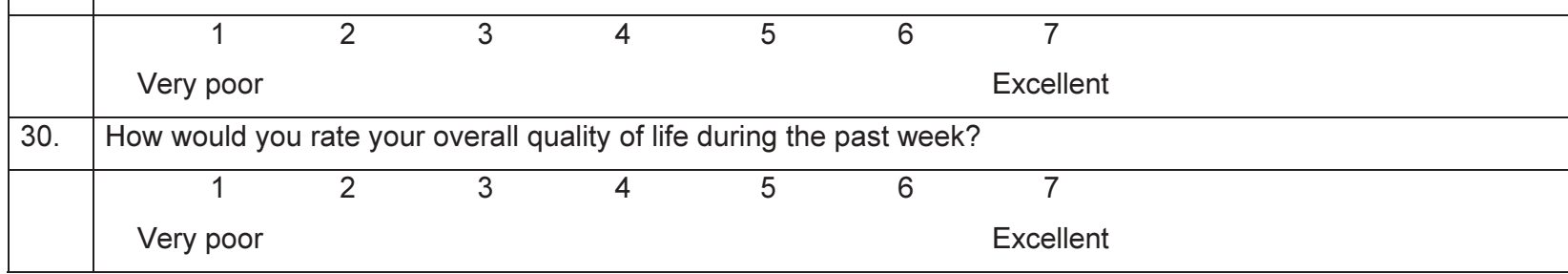

Figure 1) Quality of life questionnaire 


\begin{tabular}{|c|c|c|c|c|c|}
\hline \multicolumn{2}{|r|}{ During the last week: } & \multirow[t]{2}{*}{ Not at all } & \multirow[t]{2}{*}{ A little } & \multirow[t]{2}{*}{ Quite a bit } & \multirow[t]{2}{*}{ Very much } \\
\hline 31. & Was your physical power decreased? & & & & \\
\hline 32. & Did you have to change your eating habits? & & & & \\
\hline 33. & Did you lose weight? & & & & \\
\hline 34. & Did you have fever or shivering? & & & & \\
\hline 35. & Did you notice yellow staining of your eyes or skin? & & & & \\
\hline 36. & Did you feel bloated? & & & & \\
\hline 37. & Did you feel thirsty more often than usual? & & & & \\
\hline 38. & Did you feel sudden colicky pain? & & & & \\
\hline 39. & Did you feel a lack of appetite? & & & & \\
\hline 40. & Have you felt itching? & & & & \\
\hline \multicolumn{6}{|c|}{ Did you feel pain } \\
\hline 41. & before or after eating? & & & & \\
\hline 42. & in straight body position? & & & & \\
\hline 43. & in your belly, radiating to the back? & & & & \\
\hline 44. & at other sites? & & & & \\
\hline \multicolumn{6}{|c|}{ If yes } \\
\hline 45. & Did you take analgesics? & & & & \\
\hline 46. & If yes, did they help you? & & & & \\
\hline \multirow[t]{4}{*}{47.} & Did your defecation rate bother you & & & & \\
\hline & a, in your everyday work? & & & & \\
\hline & b, in your leisure time (movie, sport)? & & & & \\
\hline & c, in your everyday life style? & & & & \\
\hline \multirow[t]{4}{*}{48.} & Did the urgency of defecation bother you & & & & \\
\hline & a, in your everyday work? & & & & \\
\hline & b, in your leisure time (movie, sport)? & & & & \\
\hline & c, in your everyday life style? & & & & \\
\hline \multirow[t]{3}{*}{49.} & \multicolumn{5}{|l|}{ How much has the medical treatment burdened you? } \\
\hline & 3 & 6 & \\
\hline & Not at all & \multicolumn{2}{|c|}{ Very much } & & \\
\hline 50. & \multicolumn{5}{|l|}{ In what way has the medical treatment burdened you? } \\
\hline 51. & \multicolumn{5}{|c|}{ Besides the medical treatment, what has helped you the most so far? } \\
\hline \multirow[t]{3}{*}{52.} & \multicolumn{5}{|c|}{ How confident are you regarding your health for the near future? } \\
\hline & 2 & 6 & & & \\
\hline & Hardly confident & Very & fident & & \\
\hline
\end{tabular}

Figure 1(continued) Quality of life questionnaire

reduced and the patients gained weight after pancreatic enzyme supplementation in both groups. Additionally, the working ability, the cognitive functioning, the financial strain and the overall QoL scores were improved significantly after one month of enzyme replacement therapy. The QoL scores were also increased significantly in group 2 , where the patients had already been treated with pancreatic preparations. Indeed, patients in group 2 seemed to have more severe chronic pan- creatitis than those in group 1 because group 2 patients had significantly more severe exocrine pancreatic insufficiency as measured by functional tests, or the degree of steatorrhea. Therefore, this group of chronic pancreatitis patients requires proper and individually tailored enzyme replacement therapy. The reasons for the unsatisfactory treatment in this group were an inappropriate dose of enzyme replacement therapy; the use of macrosphere preparations; the lack of treatment of hyper- 
TABLE 2

Results of quality of life scores in group 1

\begin{tabular}{|c|c|c|c|c|}
\hline Scales & Items & Pretreatment score & Follow-up score & Significance \\
\hline Body weight $(\mathrm{kg})$ & & $67.7 \pm 3.8$ & $67.9 \pm 3.1$ & $P=0.049$ \\
\hline Defecation/week & & $12.1 \pm 1.1$ & $9.4 \pm 0.8$ & $P=0.023$ \\
\hline Physical status & $1-5$ & $81.3(20-100)$ & $84.5(20-100)$ & $P=0.190$ \\
\hline Working ability & 6,7 & $77.4(0-100)$ & $82.3(0-100)$ & $P=0.043$ \\
\hline General symptoms & $8-19$ & $47.4(11.1-88.8)$ & $33.9(0-86.1)$ & $P=0.000$ \\
\hline Cognitive & 20,25 & $66.1(0-100)$ & $73.6(16.6-100)$ & $P=0.042$ \\
\hline Emotional & $21-24$ & $43.0(0-100)$ & $48.6(0-100)$ & $P=0.150$ \\
\hline Social & 26,27 & $81.2(0-100)$ & $79.0(0-100)$ & $P=0.505$ \\
\hline Financial strain & 28 & $59.1(0-100)$ & $67.7(0-100)$ & $P=0.004$ \\
\hline Global quality of life & 29,30 & $43.9(8.3-66.6)$ & $53.3(33.3-83.3)$ & $P=0.005$ \\
\hline Disease-specific symptoms & $31-48$ & $28.8(1.3-72.2)$ & $23.3(0-55.5)$ & $P=0.003$ \\
\hline Treatment strain & 49 & $58.0(16.6-100)$ & $64.4(33.3-100)$ & $P=0.310$ \\
\hline Hope and confidence & 52 & $25.6(0-66.6)$ & $23.7(0-66.6)$ & $P=0.399$ \\
\hline Pain & $9,19,38,41-46$ & $47.1(0-90.5)$ & $35.9(0-90.5)$ & $P=0.001$ \\
\hline
\end{tabular}

TABLE 3

Results of quality of life scores in group 2

\begin{tabular}{|c|c|c|c|c|}
\hline Scales & Items & Pretreatment score & Follow-up score & Significance \\
\hline Body weight (kg) & & $63.3 \pm 3.3$ & $63.7 \pm 3.6$ & $P=0.0047$ \\
\hline Defecation/week & & $13.9 \pm 1.8$ & $11.5 \pm 1.3$ & $P=0.002$ \\
\hline Physical status & $1-5$ & $83.1(20-100)$ & $84.1(40-100)$ & $P=0.776$ \\
\hline Working ability & 6,7 & $74.3(50-100)$ & $83.3(50-100)$ & $P=0.042$ \\
\hline General symptoms & $8-19$ & $48.9(5.5-88.8)$ & $39.5(0-83.3)$ & $P=0.000$ \\
\hline Cognitive & 20,25 & $77.5(0-100)$ & $78.2(16.6-100)$ & $P=0.916$ \\
\hline Emotional & $21-24$ & $48.5(0-100)$ & $56.2(16.6-100)$ & $P=0.067$ \\
\hline Social & 26,27 & $68.7(0-100)^{*}$ & $71.2(0-100)$ & $P=0.223$ \\
\hline Financial strain & 28 & $45.0(0-100)^{*}$ & $63.3(0-100)$ & $P=0.000$ \\
\hline Global quality of life & 29,30 & $35.1(0-66.6)$ & $48.4(16.6-83.3)$ & $P=0.013$ \\
\hline Disease-specific symptoms & $31-48$ & $29.0(0-76.4)$ & $22.1(0-56.9)$ & $P=0.002$ \\
\hline Treatment strain & 49 & $59.9(16.6-100)$ & $59.9(0-100)$ & $P=0.519$ \\
\hline Hope and confidence & 52 & $51.1(16.6-100)^{*}$ & $47.8(16.6-100)^{*}$ & $P=0.429$ \\
\hline Pain & $9,19,38,41-46$ & $37.8(9.5-85.7)$ & $29.4(0-85.7)$ & $P=0.008$ \\
\hline
\end{tabular}

*Significant difference versus group $1(P<0.05)$

acidity; an untreated intestinal infection; or the lack of patient compliance. After correction of these underlying causes through an increased dose of pancreatic enzyme therapy, the use of $\mathrm{pH}$-sensitive pancreatic microsphere preparations, administration of an acid blocker and the improvement of compliance, an improved QoL was achieved in this group of patients, too.

Significant correlations were found in both groups between the increase in the QoL and two external variables: the increase in body weight and the decrease in steatorrhea. This demonstrates that our questionnaire is a valid tool with which to assess the QoL of patients with chronic pancreatitis.

\section{CONCLUSIONS}

Dietary counselling and pancreatic enzyme replacement therapy in patients with chronic pancreatitis not only reduced the extents of steatorrhea and pain, but also significantly improved a variety of other symptoms and the patient's QoL. Individually tailored enzyme replacement therapy improved the QoL of patients with chronic pancreatitis not only in the untreated patients, but even in those who had previously been inadequately treated. This study also demonstrated that the
EORTC QLQ-C30 questionnaire, with the addition of two further questions, is a useful tool for evaluation of the QoL in chronic pancreatitis patients. An assessment of the $\mathrm{QoL}$ should be included in evaluations of the efficacy of different treatment options in chronic pancreatitis.

\section{REFERENCES}

1. Lankisch PG. Natural course of chronic pancreatitis. Pancreatology 2001;1:3-14.

2. Lankisch PG, Banks PA. Chronic pancreatitis: Treatment. In: Lankisch PG, Banks PA, eds. Pancreatitis. Heidelberg: SpringerVerlag, 1998:303-46.

3. Glasbrenner B, Adler G. Evaluating pain and the quality of life in chronic pancreatitis. Int J Pancreatol 1997;22:163-70.

4. Steer ML, Waxman I, Freedman S. Chronic pancreatitis. N Engl J Med 1995;332:1482-90.

5. Lancet Editorial. Quality of life and clinical trials. Lancet 1995;346:1-2.

6. Aaronson NK, Bullinger M, Ahmedzai S. A modular approach to quality of life assessment in cancer clinical trials. Recent Results Cancer Res 1988;111:231-49.

7. Aaronson NK, Ahmedzai S, Berman B, et al. The European organization for research and treatment of cancer QLQ-C30: A quality of life instrument for use in international clinical trials in oncology. J Natl Cancer Inst 1993;85:365-76. 
8. Bloechle C, Izbicki JR, Knoefel WT, Kuechler T, Broelsch CE. Quality of life in chronic pancreatitis - results after duodenumpreserving resection of the head of the pancreas. Pancreas 1995;11:77-85.

9. Kahl S, Zimmermann S, Leodolter A, et al. Quality of life in patients with chronic pancreatitis after medical treatment. Pancreatology 2001;1:145. (Abst)

10. Martin J, Ratia T, Gutiérrez A, et al. Qualitity of life and outcomes after surgical treatment of chronic pancreatitis. Pancreatology 2001;1:193. (Abst)

11. Tihanyi B, Csapó ZS, Farkas I, et al. Quality of life and nutritional status after surgery for chronic pancreatitis: A longitudinal followup study. Pancreatology 2001;1:193. (Abst)

12. Izbicki JR, Bloechle C, Broering DC, et al. Extended drainage versus resection in surgery for chronic pancreatitis. Ann Surg 1998;6:771-9.

13. Witzigmann H, Max D, Uhlmann D, et al. A prospective trial comparing classical Whipple procedure and duodenum-preserving pancreatic head resection. J Gastrointest Surg 2002:2:173-80.

14. Lebenthal E, Rolston DDK, Holsclaw DS. Enzyme therapy for pancreatic insufficiency: Present status and future needs. Pancreas 1994;9:1-12.

15. Bruno MJ, Haverkort EB, Tytgat GNJ, van Leeuwen DJ. Maldigestion associated with exocrine pancreatic insufficiency: Implications of gastrointestinal physiology and properties of enzyme preparations for a cause-related and patient-tailored treatment. Am J Gastroenterol 1995;90:1383-93.

16. Isaksson F, Ihse I. Pain reduction by an oral pancreatic enzyme preparation in chronic pancreatitis. Dig Dis Sci 1983;28:97-102.

17. Slaff J, Jacobson D, Tillmann CR, Curington C, Toskes PP. Protease-specific suppression of pancreatic exocrine secretion. Gastroenterology 1984;87:44-52.

18. Czakó L, Hajnal F, Németh J, Lonovics J. Assessment of pancreatic enzyme secretory capacity by a modified Lundh test. Int J Pancreatol 2000;27:13-9.
19. Silverman FN, Shirley HC. A fat absorption test using iodized oil with particular application as a screening test in the diagnosis of fibrocystic disease of the pancreas. Pediatrics $1955 ; 15: 143-7$

20. Czakó L, Takács T, Farkas GY, Boda K, Lonovics J. Diagnostic value of faecal elastase test in exocrine pancreatic insufficiency. Orvosi Hetilap 1999;34:1887-90.

21. Kaspar P, Moeller G, Wahlefeld AW, Staehler F. A new photometric method for determination of chymotrypsin in stool. Fresenius Z Anal Chem 1982;311:391-2.

22. Ammann RW, Akovbiantz A, Largiader F, Schueler G. Course and outcome of chronic pancreatitis: Longitudinal study of a mixed medical-surgical series of 245 patients. Gastroenterology 1984;86:820-8.

23. Mössner J. Is there a place for pancreatic enzymes in the treatment of pain in chronic pancreatitis? Digestion 1993;54(Suppl 2):35-9.

24. Neuhaus H. Therapeutic pancreatic endoscopy. Endoscopy 2000;32:217-25

25. Adamek HE, Jakobs R, Buttmann A. Long term follow up of patients with chronic pancreatitis and pancreatic stones treated with extracorporeal shock wave lithotripsy. Gut 1999;45:402-5.

26. Büchler MW, Friess H, Müller MW, Wheatley AM, Beger HG. Randomized trial of duodenum-preserving pancreatic head resection versus pylorus-preserving Whipple in chronic pancreatitis. Am J Surg 1995;169:65-70.

27. Howell JG, Johnson LW, Sehon JK, Lee WC. Surgical management for chronic pancreatitis. Am Surg 2001;67:487-90.

28. Oláh A, Pardavi G, Belágyi T, Wellner I, Nagy SA. Long-term follow-up results of surgery for chronic pancreatitis. Magyar Sebészet 2000;53:13-6

29. Talamini G, Bassi C, Butturini G, et al. Outcome and quality of life in chronic pancreatitis. J Pancreas 2001;2:117-23.

30. Izbicki JR, Bloechle C, Knoefel WT, Rogiers X, Kuechler T. Surgical treatment of chronic pancreatitis and quality of life after operation. Surg Clin North Am 1999;4:913-44. 


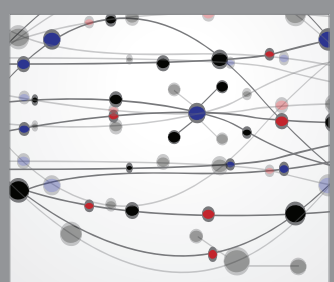

The Scientific World Journal
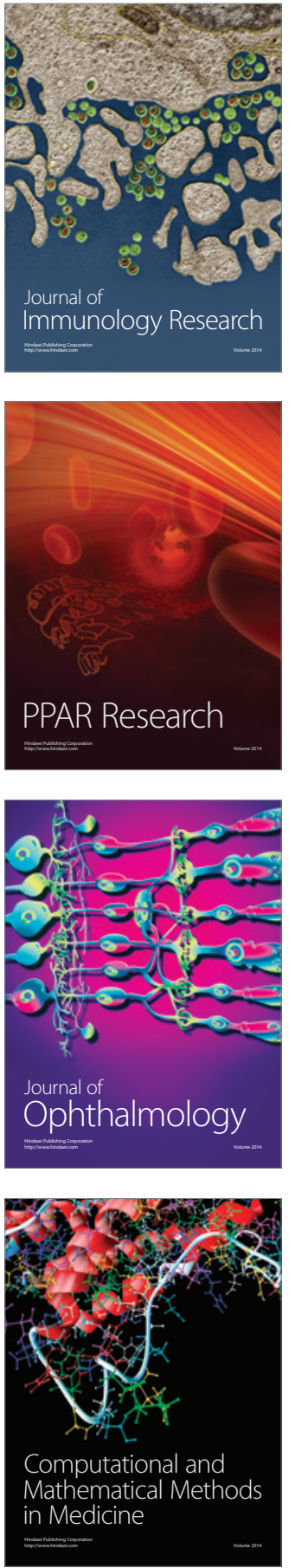

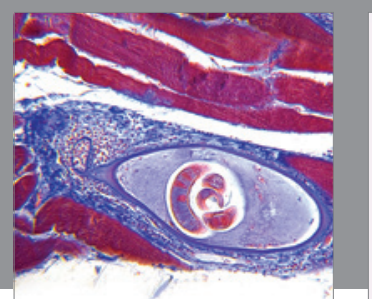

Gastroenterology Research and Practice

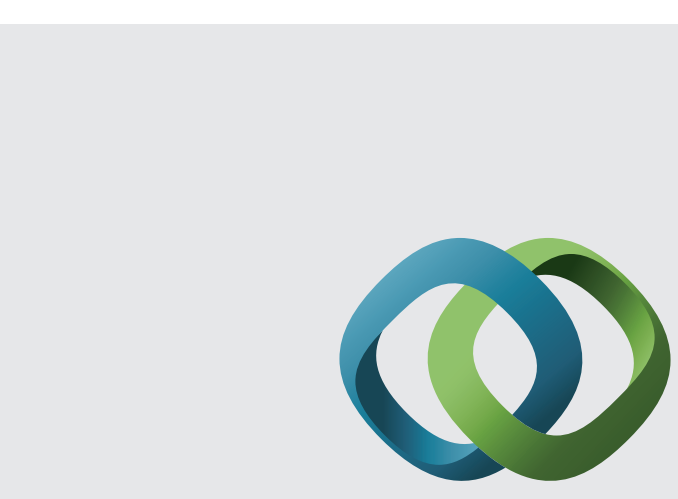

\section{Hindawi}

Submit your manuscripts at

http://www.hindawi.com
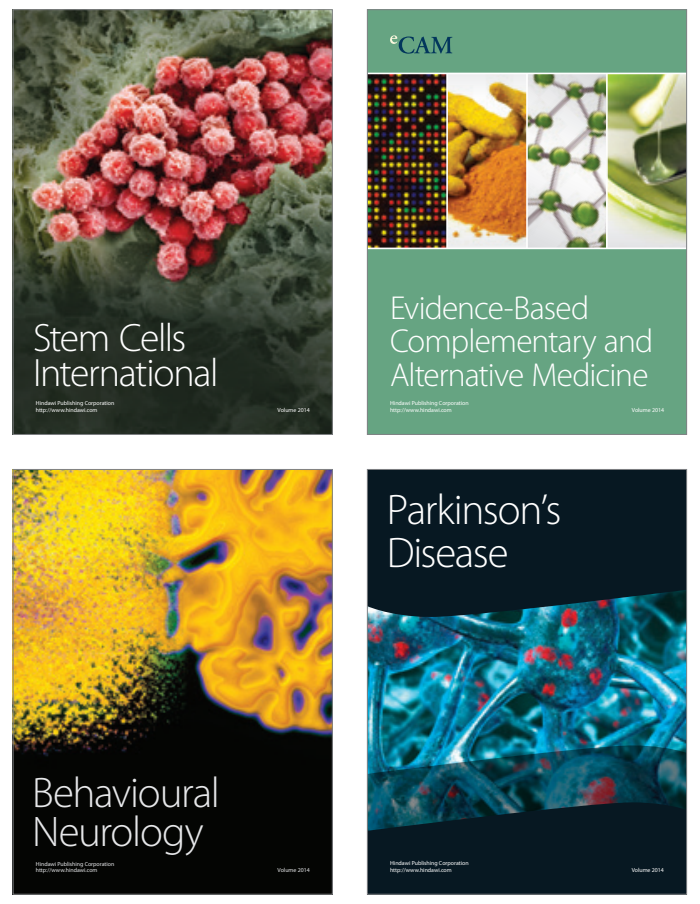
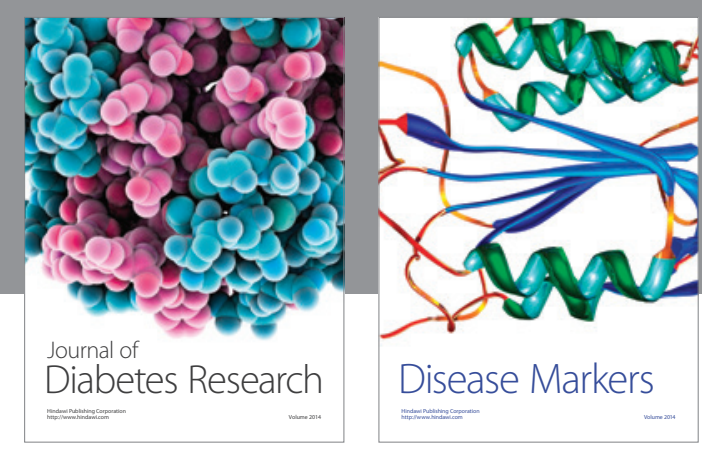

Disease Markers
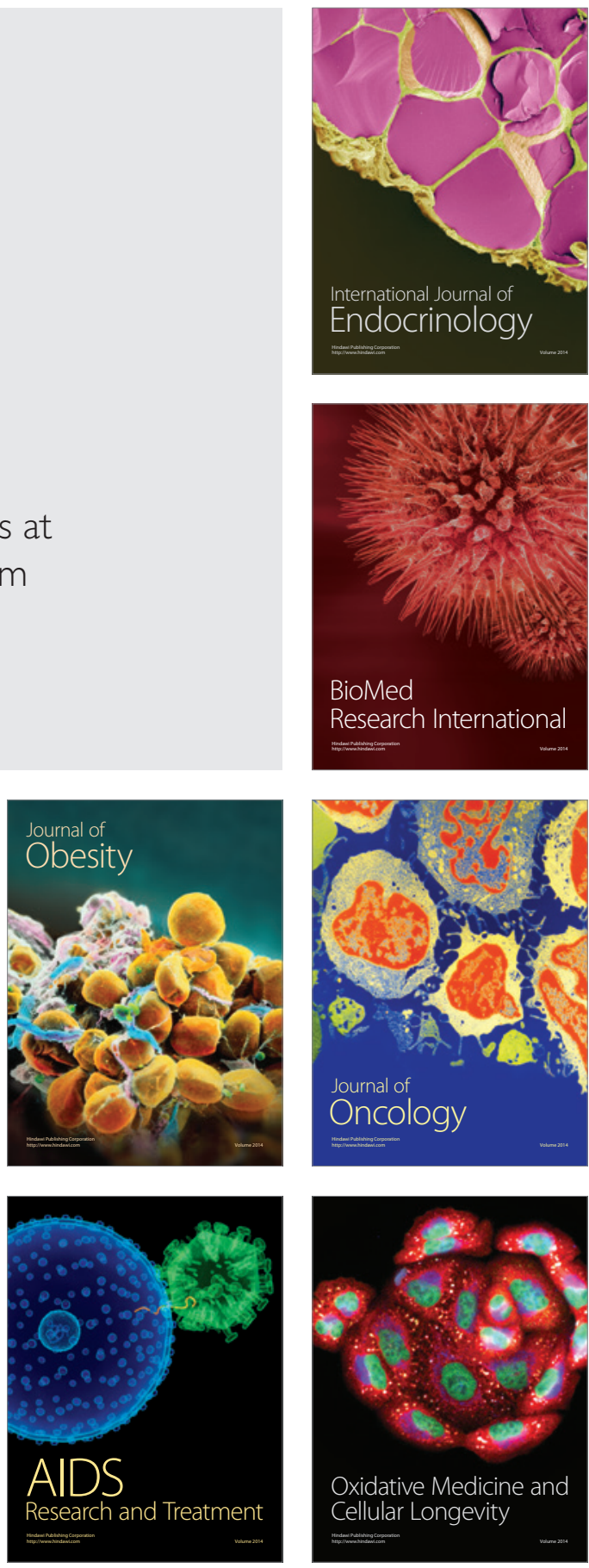